\title{
Screening for common respiratory diseases among Israeli adolescents
}

\author{
Yaron Bar Dayan MD MHA*, Keren Elishkevits MD*, Liav Goldstein MD MHA, Avishay Goldberg PhD, \\ Michel Fichler PhD, Nisim Ohana MD MPA, Yehezkel Levi MD, Yosefa Bar Dayan MD MHA
}

Y Bar Dayan, K Elishkevits, L Goldstein, et al. Screening for common respiratory diseases among Israeli adolescents. Can Respir J 2004;11(4):298-300.

BACKGROUND: Respiratory diseases are responsible for a significant proportion of serious morbidity among adolescents. There are few reports on the prevalence of common respiratory disorders in this population. The previous studies focused on specific diseases and screened relatively small samples.

OBJECTIVE: To define the prevalence of different common respiratory disorders among 17-year-old Israeli conscripts.

DESIGN: All 17-year-old Israeli nationals are obliged by law to appear at the Israel Defense Forces recruiting office for medical examination. Respiratory disease specialists evaluated and classified nominees with suspected respiratory disorders.

RESULTS: A high prevalence of respiratory morbidity was found among 94,805 17-year-old conscripts (61.5\% male, 39.5\% female). The most prevalent diagnosis was asthma (in $8 \%$ of male and $6.8 \%$ of female subjects). Fifty-five per cent of the asthma patients suffered from moderate to severe disease. The prevalence of chronic obstructive pulmonary disease was $0.03 \%$ for the male and $0.01 \%$ for the female subjects. A difference in morbidity patterns between male and female adolescents was noted, particularly in the prevalence of chest deformation and spontaneous pneumothorax.

CONCLUSIONS: The most prevalent respiratory disorder among 17-year-old Israeli conscripts was asthma. One-half of the asthma patients in this study suffered from moderate to severe disease. The prevalence of other respiratory disorders was much lower.

Key Words: Adolescents; Asthma; Israel; Prevalence

\section{Dépistage des maladies respiratoires répandues chez les adolescents israéliens}

HISTORIQUE : On attribue aux maladies respiratoires une importante proportion de la morbidité grave affectant les adolescents. Peu de rapports ont porté sur la prévalence des maladies respiratoires répandues dans cette tranche de la population. Dans le passé, des études se sont penchées sur des maladies spécifiques et ont effectué un dépistage auprès d'échantillons relativement petits.

OBJECTIFS : Définir la prévalence de diverses maladies respiratoires courantes chez des recrues militaires israéliennes de 17 ans.

MODÈLES : La Loi oblige tous les Israéliens de 17 ans à subir un examen médical au centre de recrutement des forces armées israéliennes. Des pneumologues ont procédé à l'examen et à la classification des candidats chez qui ils soupçonnaient une maladie respiratoire.

RÉSULTATS : Une forte prévalence de morbidité respiratoire a été observée parmi les 94805 conscrits de 17 ans (61,5\% d'hommes, 39,5\% de femmes). Le diagnostic le plus prévalent a été l'asthme (chez $8 \%$ des hommes et $6,8 \%$ des femmes). Chez les cinquante-cinq pour cent de conscrits atteints, l'asthme était de degré modéré à grave. La prévalence de la maladie obstructive pulmonaire chronique était de 0,03\% chez les hommes et de 0,01\% chez les femmes. Une différence a été observée quant au mode de présentation de la maladie entre les hommes et les femmes, particulièrement en ce qui a trait à la prévalence de la déformation du thorax et du pneumothorax spontané.

CONCLUSION : Le trouble respiratoire le plus prévalent chez les conscrits israéliens de 17 ans est l'asthme. La moitié des patients asthmatiques dans le cadre de cette étude souffraient de la maladie à un degré modéré à grave. La prévalence des autres troubles respiratoires s'est révélée beaucoup plus faible.
$\mathbf{R}$ espiratory diseases are responsible for a significant proporRtion of serious morbidity and premature death. Recent reports from the United Kingdom showed that respiratory diseases accounted for $6.5 \%$ of hospital admissions and $24 \%$ of all deaths (1). An American survey on the use of physician offices by adolescents showed that for the age groups 11 to 14 years and 18 to 21 years, the leading reason for visits were respiratory disorders (19.4\% and $11.3 \%$, respectively) (2). There are few reports on the prevalence of different respiratory disorders among adolescents. In this study, the Israeli recruiting office medical database was used to determine the prevalence of common respiratory disorders among 17-year-old Israeli conscripts.

\section{Source of data}

\section{PATIENTS AND METHODS}

All 17-year old Israeli nationals are obliged by law to appear at the Israel Defense Forces (IDF) recruiting office for medical examination.
Included in the current study are all the nominees for military service between January 1 and December 31, 2001.

\begin{abstract}
Medical surveillance
Military physicians performed the medical examinations in the recruiting office. Medical histories were obtained from the family physicians of most conscripts. During the examination, the subjects were asked to note specifically any diagnoses of medical conditions that they had received in the past. The conscripts were classified according to strictly defined guidelines and regulations. Conscripts with a known respiratory disorder, or with respiratory symptoms such as dyspnea, cough or exercise intolerance, were referred to a trained respiratory physician for a second examination. The second examination included a further detailed history, physical examination, spirometry at rest, and radiological and laboratory tests as needed. All subjects with overt clinical signs and spirometry evidence of severe
\end{abstract}

*The first two authors had equal contribution to this article

Surgeon General Headquarters, Israel Defense Forces Medical Corps, Faculty of Medicine, Ben Gurion University, Beer Sheba, Israel Correspondence: Dr Yaron Bar Dayan, Israeli Air Force and Faculty of Medicine, Ben Gurion University, Beer Sheba, 16th Dolev Street,

Neve-Savion, Or-Yehuda, Israel. Telephone+972-3-6341039, e-mail bardayan@netvision.net.il 
TABLE 1

Severity grading for the four most prevalent respiratory disorders

\begin{tabular}{|c|c|c|c|c|}
\hline $\begin{array}{l}\text { Grade of } \\
\text { severity }\end{array}$ & Asthma & Restrictive lung disease & Chest deformation & Tuberculosis \\
\hline 0 & $\begin{array}{c}\text { Total remission for at least } \\
\text { three years; } \mathrm{FEV}_{1}>80 \%\end{array}$ & $\begin{array}{l}\text { History of disease injury or surgery } \\
\text { with complete remission; TLC> }>80 \% \text {, } \\
\text { DLCO }>80 \%\end{array}$ & $\begin{array}{l}\text { Very mild deformation with normal } \\
\text { spirometry; } \mathrm{FEV}_{1}>80 \% \text {, TLC }>80 \% \text {, } \\
\text { DLCO }>80 \%\end{array}$ & $\begin{array}{l}\text { History of tuberculosis } \\
\text { infection with normal } \\
\text { current lung function }\end{array}$ \\
\hline A & $\begin{array}{l}\text { Rare and mild attacks with } \\
\text { normal spirometry; FEV }>80 \%\end{array}$ & Not defined & Not defined & Not defined \\
\hline B & Not defined & $\begin{array}{l}\text { Mild restrictive disorder with mildly } \\
\text { abnormal spirometry; TLC } 70 \% \\
\text { to } 80 \% \text {, DLCO } 70 \% \text { to } 80 \%\end{array}$ & $\begin{array}{l}\text { Chest deformation and mildly abnormal } \\
\text { spirometry; FEV } 170 \% \text { to } 80 \% \text {, } \\
\text { TLC } 70 \% \text { to } 80 \% \text {, DLCO } 70 \% \text { to } 80 \%\end{array}$ & Not defined \\
\hline C & $\begin{array}{l}\text { Stable asthma with regular daily } \\
\text { treatment; } \mathrm{FEV}_{1} 70 \% \text { to } 80 \%\end{array}$ & Not defined & Not defined & $\begin{array}{l}\text { Active tuberculosis infection } \\
\text { according to radiographic } \\
\text { evidence and Mantoux test }\end{array}$ \\
\hline$D$ & $\begin{array}{l}\text { Moderately active disease despite } \\
\text { treatment; } \mathrm{FEV}_{1} 50 \% \text { to } 69 \% ; \\
\text { treatment with inhaled steroids }\end{array}$ & $\begin{array}{l}\text { Restrictive disorder with moderately } \\
\text { abnormal spirometry; TLC } 50 \% \\
\text { to } 69 \% \text {, DLCO } 60 \% \text { to } 69 \%\end{array}$ & $\begin{array}{l}\text { Chest deformation with moderately } \\
\text { abnormal spirometry; FEV } 150 \% \text { to } 69 \% \text {, } \\
\text { TLC } 50 \% \text { to } 69 \% \text {, DLCO } 60 \% \text { to } 69 \%\end{array}$ & Not defined \\
\hline$E$ & $\begin{array}{l}\text { Severe asthma treated temporarily } \\
\text { with oral steroids; unstable } \mathrm{FEV}_{1}\end{array}$ & $\begin{array}{l}\text { Severe restrictive disorder with } \\
\text { abnormal spirometry but good } \\
\text { prognosis }\end{array}$ & Not defined & Not defined \\
\hline $\mathrm{F}$ & $\begin{array}{l}\text { Severe asthma treated regularly } \\
\text { with oral steroids and with } \\
\text { intravenous steroids in severe } \\
\text { attacks; } \mathrm{FEV}_{1}<50 \%\end{array}$ & $\begin{array}{l}\text { Severe restrictive disorder with } \\
\text { abnormal spirometry; TLC }<50 \% \text {, } \\
\text { DLCO }<60 \%\end{array}$ & $\begin{array}{l}\text { Significant chest deformation with } \\
\text { severe respiratory and cardiac } \\
\text { dysfunction; } \mathrm{FEV}_{1}<50 \% \\
\text { TLC }<50 \% \text {, DLCO }<60 \%\end{array}$ & $\begin{array}{l}\text { Resistant tuberculosis } \\
\text { infection or significant } \\
\text { disease complications }\end{array}$ \\
\hline
\end{tabular}

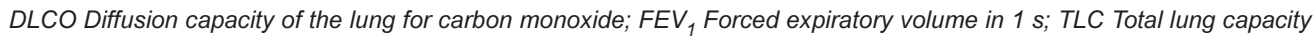

airway obstruction also underwent an exercise test. The test was $6 \mathrm{~min}$ of treadmill running at $5 \mathrm{~km} / \mathrm{h}$, arriving at an incline of 10 degrees, while breathing room air $\left(22^{\circ} \mathrm{C}, 50 \%\right.$ relative humidity). Lung function was measured $5 \mathrm{~min}$ and $10 \mathrm{~min}$ after exercise to determine the percentage of fall in forced expiratory volume in $1 \mathrm{~s}$.

\section{Disease categories}

The respiratory disorders were classified into the following categories:

1. Chronic obstructive pulmonary disease (COPD), except asthma: Diagnosed by clinical history, spirometry, an exercise test and a respiratory physician.

2. Asthma: Diagnosed by clinical history, spirometry, an exercise test and a respiratory physician.

3. Restrictive lung disease: This category included patients with a restrictive disorder in spirometry, such as those suffering from cystic fibrosis, bronchiectasis and sarcoidosis.

4. Chest deformation: A clinical diagnosis, also defined by spirometry and echocardiography in severe cases.

5. Tuberculosis: Diagnosis depended on medical history, chest film findings and Mantoux test.

6. Spontaneous pneumothorax or pneumomediastinum: Diagnosis based on medical history.

\section{Disease severity}

The conscripts were also classified according to the severity of their condition and activity limitation. Seven categories were defined, from very mild disorder with no activity limitation to severe disorder and significant activity limitation, which can prevent recruitment. A sample of this classification is presented in Table 1 .
TABLE 2

Prevalences $(\%)$ of respiratory disorders in adolescent male and female subjects in a screening study of 17-year-old Israeli conscripts

\begin{tabular}{lcc}
\hline Respiratory disease & Male subjects & Female subjects \\
\hline COPD & 0.03 & 0.01 \\
Asthma & 8.07 & 6.82 \\
Restrictive lung disease & 0.16 & 0.10 \\
Chest deformation & 1.33 & 0.24 \\
Tuberculosis & 0.25 & 0.16 \\
Spontaneous pneumothorax & 0.15 & 0.05 \\
and pneumomediastinum & & \\
\hline
\end{tabular}

COPD Chronic obstructive pulmonary disorder

\section{Statistical description}

All data were recorded on a computer and analyzed later. These data were used to describe the prevalence of common respiratory disease in a specific population - 17-year-old adolescents. Because of the large size of this database, small differences between the sexes were disregarded.

\section{RESULTS}

The survey included 94,805 adolescent subjects - 36,511 $(38.5 \%)$ were female and 58,295 (61.5\%) were male. Table 2 presents the prevalence of the different respiratory disorders for both sexes. The most prevalent diagnosis was asthma (in $8 \%$ of male and $6.8 \%$ of female subjects). The four most prevalent diagnoses were graded according to their severity as presented in Table 1. Table 3 presents the prevalence of the different severity grades. A prominent finding was that approximately $55 \%$ of the asthma diagnoses were graded as moderate to 
TABLE 3

Prevalences $(\%)$ of severity grades for common respiratory disorders in a screening study of 17-year-old Israeli conscripts

\begin{tabular}{lcccc}
\hline $\begin{array}{l}\text { Severity } \\
\text { grade }\end{array}$ & Asthma & $\begin{array}{c}\text { Restrictive } \\
\text { lung disease }\end{array}$ & $\begin{array}{c}\text { Chest } \\
\text { deformation }\end{array}$ & \begin{tabular}{l} 
Tuberculosis \\
\hline 0
\end{tabular} 16.36 $^{\text {lung }}$ \\
A & 0 & 26.70 & 92.30 & 67 \\
B & 29.80 & 0 & 0 & 0 \\
C & 39.25 & 35.10 & 4.40 & 0 \\
D & 14.22 & 0 & 0 & 21 \\
E & 0.17 & 28.24 & 2.55 & 0 \\
F & 0.20 & 0 & 0 & 0 \\
\hline
\end{tabular}

severe. The most prominent differences between sexes were noted in the prevalence of chest deformation, spontaneous pneumothorax and COPD.

\section{DISCUSSION}

A systematic description of the prevalence of respiratory disorders among adolescents is not performed routinely. The majority of previous reports studied the incidence of specific disorders within selected, small populations. The present study showed a high prevalence of respiratory disorders among 17-year-old Israeli conscripts.

The most common respiratory diagnosis in the present study was asthma. These results are compatible with recent reports that presented a significant increase in the prevalence of asthma in the pediatric population (2-5). Asthma prevalence varies between $1.6 \%$ and $36.8 \%$, with higher prevalence rates in minority, urban and low socioeconomic status populations (3). Among the possible explanations for the increased prevalence are different diagnostic criteria and changing environmental exposure because of widespread urbanization (4). Approximately 55\% of the asthma diagnoses in the present study were graded as moderate to severe, meaning that $55 \%$ of these adolescents needed regular, daily treatment and frequently used medical services.

Approximately $5 \%$ to $15 \%$ of adults in industrialized countries have COPD, defined by spirometry. This disease primarily affects men and women over the age of 45 years. The major cause of COPD is tobacco smoking $(1,6)$. The prevalence of adolescent smoking has been increasing. Cigarette smoking in adolescents has been found to be associated with mild airway obstruction and slowed growth of lung function in both sexes (7). It has also been also suggested that girls are more vulnerable than boys to the effects of smoke on lung function and respiratory symptoms (8). The prevalence of COPD reported in our study among 17-yearold adolescents (one per 100,000 female subjects, three per 100,000 male subjects) has not been reported before. Unfortunately, our database did not include information about smoking habits or secondhand exposure from parents. We can only emphasize the need to further investigate these findings.
Tuberculosis has been defined as one of the leading causes of death in the world (9). More than 25\% of adolescents in developing countries are infected (10), but this rate is much lower in developed communities. Although Israel represents an immigrant society, the prevalence of a history of tuberculosis infection in the present study was relatively low. Moreover, $67 \%$ had a history of infection in the past but normal lung function at the time of medical examination.

The prevalence of the other respiratory disorders was either very low or compatible with previous literature (11-15).

It is noteworthy that the prevalence of both chest deformations and spontaneous pneumothorax was much higher in male adolescents than female adolescents (Table 2), and that $92 \%$ of the chest deformations were mild, having no significant effect on lung function. Because of the large size of our database, these sex differences may not be clinically significant.

\section{CONCLUSIONS}

The most prevalent respiratory disorder among 17-year-old Israeli conscripts is asthma. One-half of the asthma patients in the present study suffered from moderate to severe disease. The prevalence of other respiratory disorders was much lower.

\section{REFERENCES}

1. Chung F, Barnes N, Allen M, et al. Assessing the burden of respiratory disease in the UK. Respir Med 2002;96:963-75.

2. Ziv A, Boulet JR, Slap GB. Utilization of physician offices by adolescents in the United States. Pediatrics 1999;104:35-42.

3. Cloutier MM, Wakefield DB, Hall CB, Bailit HL. Childhood asthma in an urban community: Prevalence, care system, and treatment. Chest 2002;122:1571-9.

4. Akinbami LJ, Schoendorf KC. Trends in childhood asthma: Prevalence, health care utilization, and mortality. Pediatrics 2002;110:315-22.

5. Lozano P, Sullivan SD, Smith DH, Weiss KB. The economic burden of asthma in US children: Estimates from the National Medical Expenditure Survey. J Allergy Clin Immunol 1999;104:957-63.

6. Anto JM, Vermeire P, Vestbo J, Sunyer J. Epidemiology of chronic obstructive pulmonary disease. Eur Respir J 2001;17:982-94.

7. Gold DR, Wang X, Wypij D, Speizer FE, Ware JH, Dockery DW. Effects of cigarette smoking on lung function in adolescent boys and girls. N Engl J Med 1996;335:931-7.

8. Holmen TL, Barrett-Connor E, Clausen J, Langhammer A, Holmen J, Bjermer L. Gender differences in the impact of adolescent smoking on lung function and respiratory symptoms. The Nord-Trondelag Health Study, Norway, 1995-1997. Respir Med 2002;96:796-804.

9. Murray CJL, Lopez AD. Mortality by cause for eight regions of the world: Global Burden of Disease Study. Lancet 1997;349:1269-76.

10. Donald PR. Children and tuberculosis: Protecting the next generation? Lancet 1999;353:1001-2.

11. Behrman RE, Kliegman R, Arvin AM, eds. Nelson Textbook of Pediatrics, 15th edn. Philadelphia: WB Saunders, 1997.

12. Gupta D, Hansell A, Nichols T, Duong T, Ayres JG, Strachan D. Epidemiology of pneumothorax in England. Thorax 2000;55:666-71.

13. Michel JL. Spontaneous pneumothorax in children. Arch Pediatr 2000;7(Suppl 1):39S-43S.

14. Morgan WJ, Butler SM, Johnson CA, et al. Epidemiologic study of cystic fibrosis: Design and implementation of a prospective, multicenter, observational study of patients with cystic fibrosis in the US and Canada. Pediatr Pulmonol 1999;28:231-41.

15. FitzSimmons SC. The changing epidemiology of cystic fibrosis. J Pediatr 1993;122:1-9. 


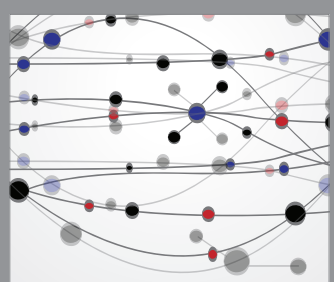

The Scientific World Journal
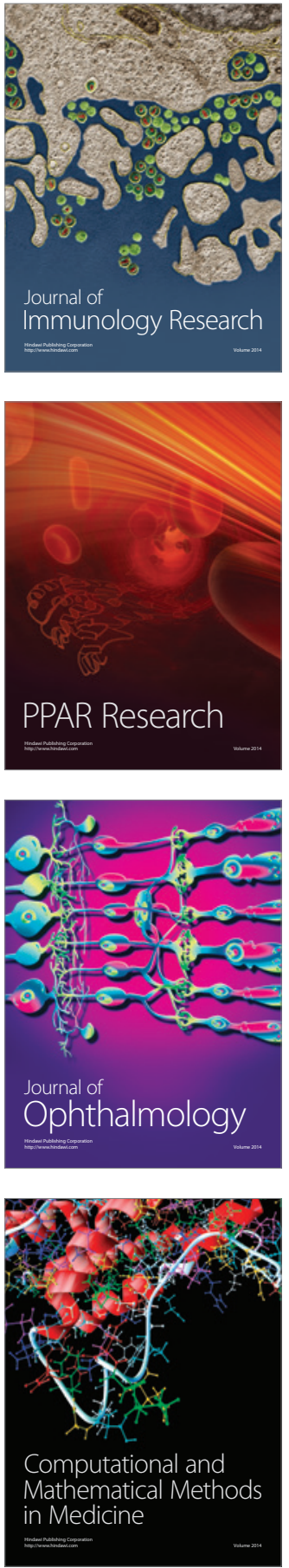

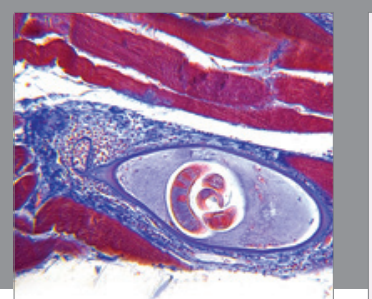

Gastroenterology Research and Practice

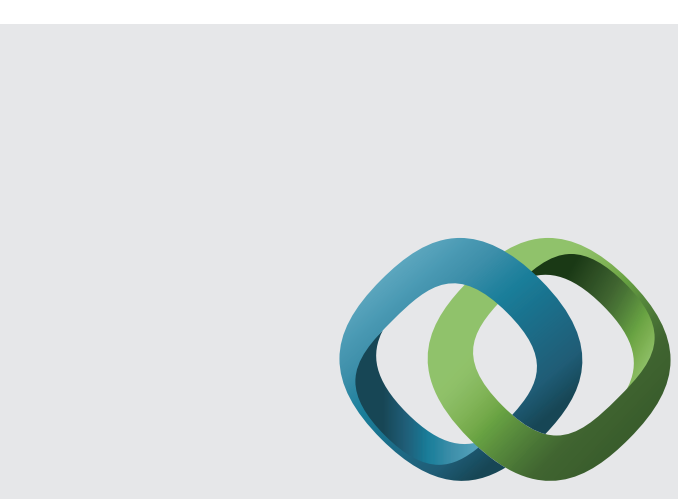

\section{Hindawi}

Submit your manuscripts at

http://www.hindawi.com
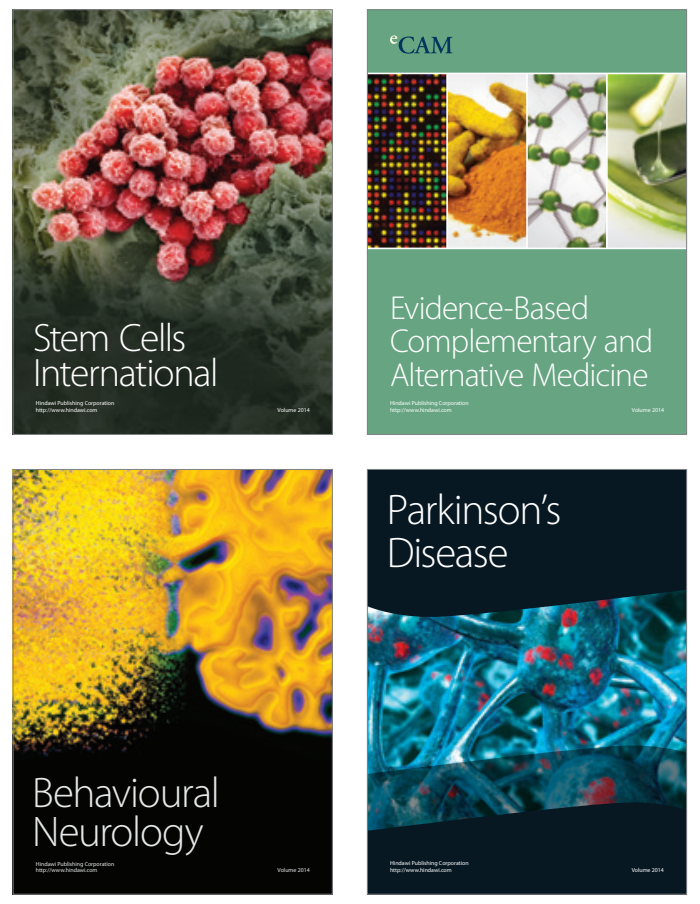
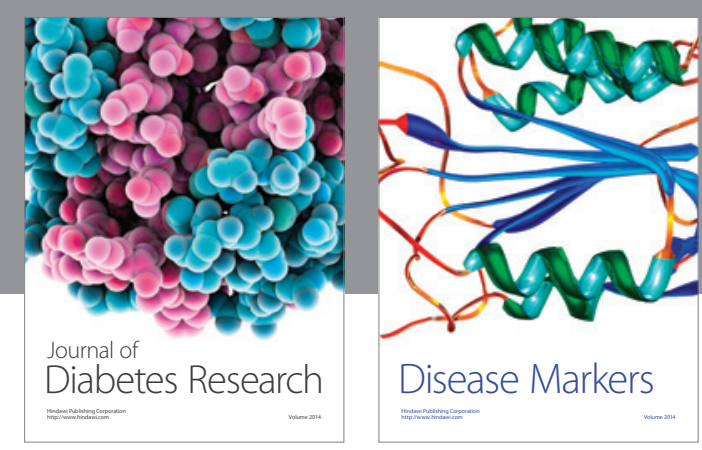

Disease Markers
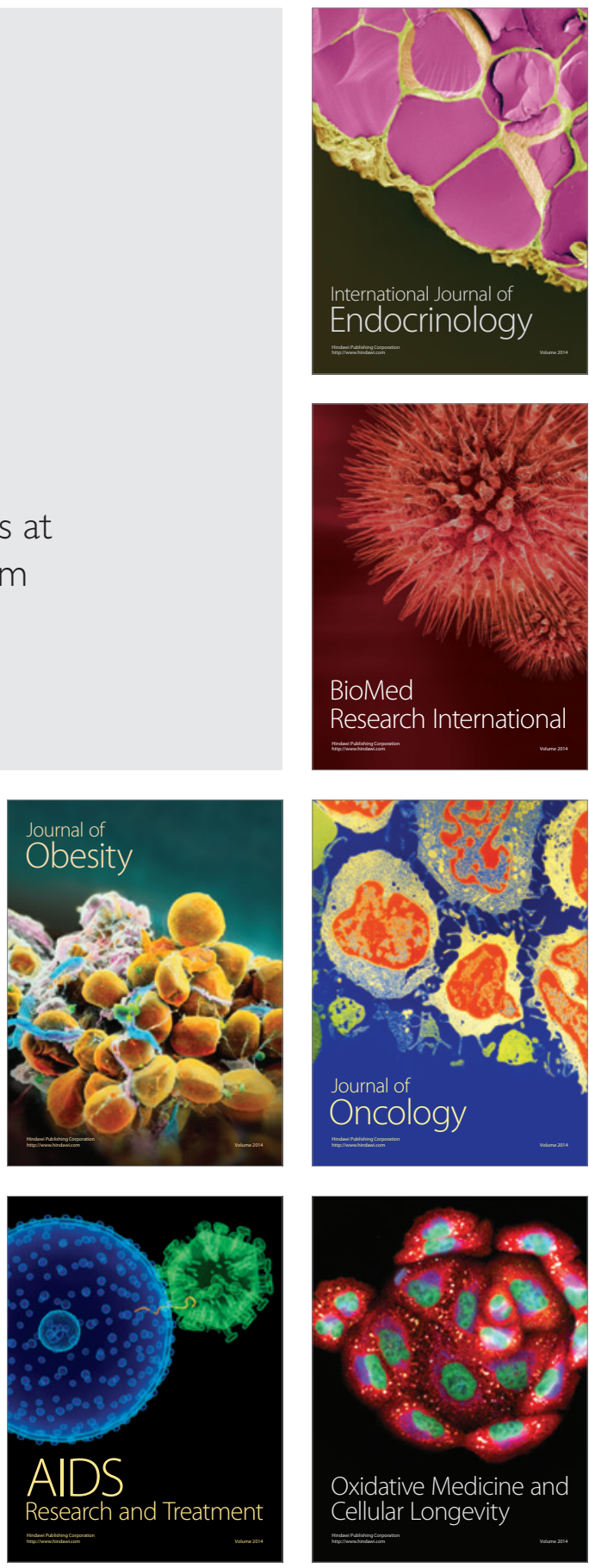